\title{
The Competence of Project Team Members and Success Factors with Open Innovation
}

\author{
Minjeong $\mathrm{Oh}^{1}$ and Sungyong Choi ${ }^{2, *(D)}$ \\ 1 Global Elite Division, Yonsei University, Wonju, Kangwon-do 26493, Korea; mj44oh@yonsei.ac.kr \\ 2 Division of Business Administration, School of Business, Hanyang University, Seoul 04763, Korea \\ * Correspondence: sungyongchoi@hanyang.ac.kr
}

Received: 20 June 2020; Accepted: 20 July 2020; Published: 22 July 2020

\begin{abstract}
The purpose of this paper is to examine the relationship between emotional, managerial, and intellectual competence of team members, which refer to the LDQ (Leadership Development Questionnaire) and impact on project success. (1) Background: Large and complex projects are being conducted in a dynamic business environment. The need for capabilities and managerial aspects of participants of the project for business performance increases. (2) Methods: A questionnaire survey was conducted on 164 project management professionals in various industries from Korea. The structural equation modeling technique was performed to establish the effect of competence of team members on project success factor. (3) Results: The results provided empirical support for the impact of team members' competencies on project success factor. Moreover, there is no difference in the perception of the impact of team members' competencies on project success factor, depending on their roles, such as project manager and team member. (4) Results: In this paper, the importance of the competence of team members in accordance with the project manager was presented. The findings of this study suggest the strategic direction of the members at this point when corporate innovation is needed.
\end{abstract}

Keywords: project team member; competence; project success factor; project management; open innovation

\section{Introduction}

Changes in the business environment of globalization, digitalization, and transformation have become fast and unpredictable. Accordingly, the ability to carry out the project has become a prerequisite for the company's development and survival. Success has become a major theme in project management, receiving remarkable attention from both researchers and practitioners [1]. The initial study of project success was about success criteria and critical success factors [2]. Recently, researchers have focused on the relationship between project manager capability and project success [3]. The ability of project managers to achieve the business strategic objective is critical to drive project performance.

Numerous studies have shown that a manager's leadership capabilities can be an important driving force for the survival and growth of the company [4]. Most studies highlight the leadership capabilities of managers in terms of administrative skills for project success within an organization. In contrast, the individual competencies of the team member, including knowledge, skills, and mindset, are presented in separate areas.

Companies and organizations must strive for the abilities and roles of all project participants in the project team to ensure continuous innovation.

ISO21500 defines a project as "a unique set of processes of coordinated and controlled activities with start and finish dates, undertaken to achieve an objective". Kerzner noted that the project organization is a goal-oriented, professional system that focuses on manpower and technologies to 
ensure project success [5]. This is related to the specificity of the project itself-the person carrying out the project performs more liberal, but with a stronger responsibility and accountability, he or she is pressured to meet the project deadline, not to exceed budget and limited resources.

With the advent of new technologies and project-driven changes in the working environment, companies are increasingly relying on teams with expertise to achieve organizational goals. Therefore, a company can no longer rely solely on the roles and control of the project manager.

The members of the project organization typically consist of project owner, project manager, project leader, and team member, depending on the cultures of the company. The project owner is the director of the business unit. Project managers who perform tasks according to the goals and scope of the project, and who are in charge of conducting, controlling, and coordinating overall project activities, are similar character to a project leader. In addition, the team members of the project perform in the best position to determine who should be responsible for a variety of roles. They communicate and collaborate with each other based on their expertise and technical skills.

Specialized project management is becoming an essential requirement for project success, and the demand for advanced features, collaboration, and management skills is increasing not only for project managers, but also to project participants. In order for the company to be innovative and sustainable, members must also change their ability to perform projects. In the future, all members should have management capabilities beyond individual abilities they own. Theoretical research supports the possibility that the most qualified team members are likely to be informally responsible for leadership [6].

In this study, we focus on the project team member's competence to influence the success factor of the project-areas not adequately covered in the literature. The purpose of this study is as follows: First, we define and investigate the capabilities of team members to need to have through research of previous research. Second, review the project success factor with a theoretical background. Third, investigate the impact of the project team members' competence on project success factor through empirical study. Additionally, ensure that there is no difference between the project manger's perception and team member's perception regarding the impact of the team member's competencies on the project success factors.

In summary, the empirical research of this study aims to show that the ability to focus on the managers is now what team members need to achieve. In a fast-changing and innovative business environment, we suggest that companies motivate growth limits to improve their competitiveness by distributing management capabilities concentrated only on managers to team members for valid [7].

\section{Theoretical Background}

\subsection{Competence}

Competence is defined as the ability or capability that the intent appears as a set of behavior [8-10]. It is possible to predict the effectiveness of the situation by understanding what behavior and intention are relevant. It is used as a critical indicator of performance in a business environment or organization. Thus, the theory of competence is the foundation for improving the performance of the organization. The abilities or capabilities of human resources in an organization are described as value, vision, knowledge, career, role responsibility, and task needed to perform [10].

The theory of competence has been studied theoretically and empirically in many research fields, from multiple perspectives. In particular, there are many studies of competence from the manager's point of view. Spencer and Spencer stated that competency is a feature that is effective concerning the criterion referenced in a job or situation and represents a relatively long-lasting behavior and mindset in various situations. The five competencies presented are motives, traits, self-concept, knowledge, and skill [11]. Competencies are defined separately as the items by managers $[8,10,12]$. There are six clusters of competencies that produce outstanding performance: cognitive intelligence competence, emotional intelligence, self-management, social intelligence, social awareness, and relationship 
management. In part, shifts in focus from the administrative to the social aspect show a broader competence trend. Many kinds of literature on competencies suggests that organizational managers require emotional intelligence, in addition to administrative aspects [13].

Most recently, competency has emerged that encompasses all early theories. Representatives of this school are Dulewicz and Higgs [14], who have extensively reviewed existing theories and assessment tools, called the LDQ (Leadership Development Questionnaire). LDQ identifies fifteen competencies, clustered under three dimensions, namely emotional competence (EQ), managerial competence $(\mathrm{MQ})$, and intellectual competence (IQ), which are defined as follows:

- Emotional competence (EQ): self-awareness, emotional resilience, intuitiveness, sensitivity, influence, motivation, and conscientiousness;

- Managerial competence (MQ): managing resources, engaging communication, empowering, developing, and achieving;

- Intellectual competence (IQ): critical analysis and judgment, vision and imagination, and strategic perspective.

\subsection{Team Member's Competence for Project Management}

Traditionally, project management is understood to succeed with the right tool and technique, regardless of the project participation's personality or project type. This is contrary to the studies of the mentioned competency theories. Case studies have been conducted gradually on the capabilities of project managers in the area of project management [15-17]. Crawford et al. mentioned that not only project management procedures, but also the project manager's competence should be applied to project management [18]. In other literature, the correlation has been shown between the competence of managers and project success in different projects [3]. There are many empirical studies on leadership and project success using LDQ questionnaires, such as the financial industry, construction industry, agile projects, and general projects [19-21].

Does the project need to focus only on the competence of the project manager in order to succeed? The project team consists mainly of the project manager and team members. The project manager (PM) or project leader (PL) is the person responsible for the entire project execution, and team members are practitioners who work with PM to understand the mission and vision of the organization and to achieve project goals.

Previous research has shown that team members involved in the project need personal competencies, such as knowledge and technical skill [22]. However, as more complex and dynamic projects increase, professional and multifunctional requirements are required to build a project team; team members also need the skills and expertise that managers need, and they must have a high level of communication, management skill, and integration capabilities, as well as the ability to utilize and understand knowledge, tools, and techniques. In this study, we suggest using the LDQ questionnaire, which measures a manager's competency to verify team members.

\subsection{Project Success Factor}

Research into the definition of project success is systematically developed. Initially, the term was defined as iron triangles of cost, time, and quality. Subsequently, project success is considered the satisfaction of stakeholders and linked to the strategic aspects of the organization [4,23,24]. Project success should be related to distinct project success factor and project success criteria. Project success factors are events, conditions, and environments that directly or indirectly contribute to the project success, while project success criteria measure whether the project is successful or not $[25,26]$.

There are ten most widely and well-known success factors, i.e., project mission, top management support, schedule and plans, client consultation, personnel, technical tasks, client acceptance, monitoring, feedback, communication, and problem-solving [27]. Recent studies have shown that managing resources, especially human resources and team, is a critical success factor that leads to 
project success [28]. The project team's capability, knowledge, and skill can contribute to the project success in the construction industry, while other studies have stated that problem-solving, commitment, teamwork, and decision-making are critical $[29,30]$.

Nguyen et al. categorized success factors into four groups: comfort, commitment, competence, and communication, called the 4 COMs [31], the relationship between soft skills and project success factors has been verified in some empirical studies based on the 4 COMs [26]. Comfort, the first success factor, represents the alignment among resources, involvement, and leadership. The components consist of proper funding through the project, resource availability, comprehensive contract documentation, continuing involvement of stakeholders, and competent project managers. This component means that the project is being implemented comfortably. Moreover, resources such as funding, human resources, efforts, and leadership should be available throughout the project lifecycle. Reasonable contracts guarantee risk and reward, and project managers' outstanding leadership ensures they "do the right thing".

The second element of success factors is competence, including the utilization of technology and experience, multidisciplinary and competent project team, and bidding with appropriate designer/contractor. For the project team with inexperienced and useless skills, cannot make quick and accurate decisions as a whole.

Third, the commitment describes the willingness and interest to achieve project success. Commitment components to the project include clear objectives and scope, and top management support. Clear objectives and scope should be informed of the direction of the project and expected results. Top management's support as a physical representation of commitment to the project is motivated.

Communication, the last component of the success factors, describes the effective and efficient information gathering and sharing; it comprises community involvement, clear communications channels, and frequent progress meeting. It is becoming more and more important today. Collecting and sharing of information are fundamental to communication, and therefore frequent meetings are inevitable. Project participants should share the project information in a sincere way and obtain different perspectives on the project.

Adopted variables in this paper were developed as success factors for the project in a study investigating practitioners who participated in large-scale construction projects in Vietnam [25]. Other researchers identified the link between these success factors and external stability, the competence of project managers and team members, and organizational support, and they provided statistical evidence to support those success factors [32]. Chen et al. shown that the 4 COMs model has a significant impact on the success of construction partners [29]. Therefore, the hypothesis of our study reveals that it was built on the theoretical basis of previous researchers, and the project success factor by Nguyen et al. was adopted as a dependent variable in this study, because it comprehensively presented project success.

\section{Research Methodology}

\subsection{Research Model}

This study aimed to determine the core competencies of project team members to carry out projects in a rapidly changing business environment successfully. As the environment changes over time, professional areas and the capacity of team members are required, and the values and awareness of project management are changing. Therefore, the emotional, managerial, and intellectual competencies of team members can contribute to the development of project management innovation.

Based on the competency and project success school through the literature review, a hypothesis model was developed to investigate the relationship between team members' competency and project success factors in Korea, as shown in Figure 1. In this model, team members' competencies are deemed as being three-dimensional, composed of an emotional dimension, managerial dimension, and intellectual dimension. Project success factors are deemed as being four-dimensional, consisting of 
comfort, competence, commitment, and communication. To empirically test this hypothesis model, structural equation modeling (SEM) was adopted, and the developed model was verified through confirmatory factor analysis and structural equations.

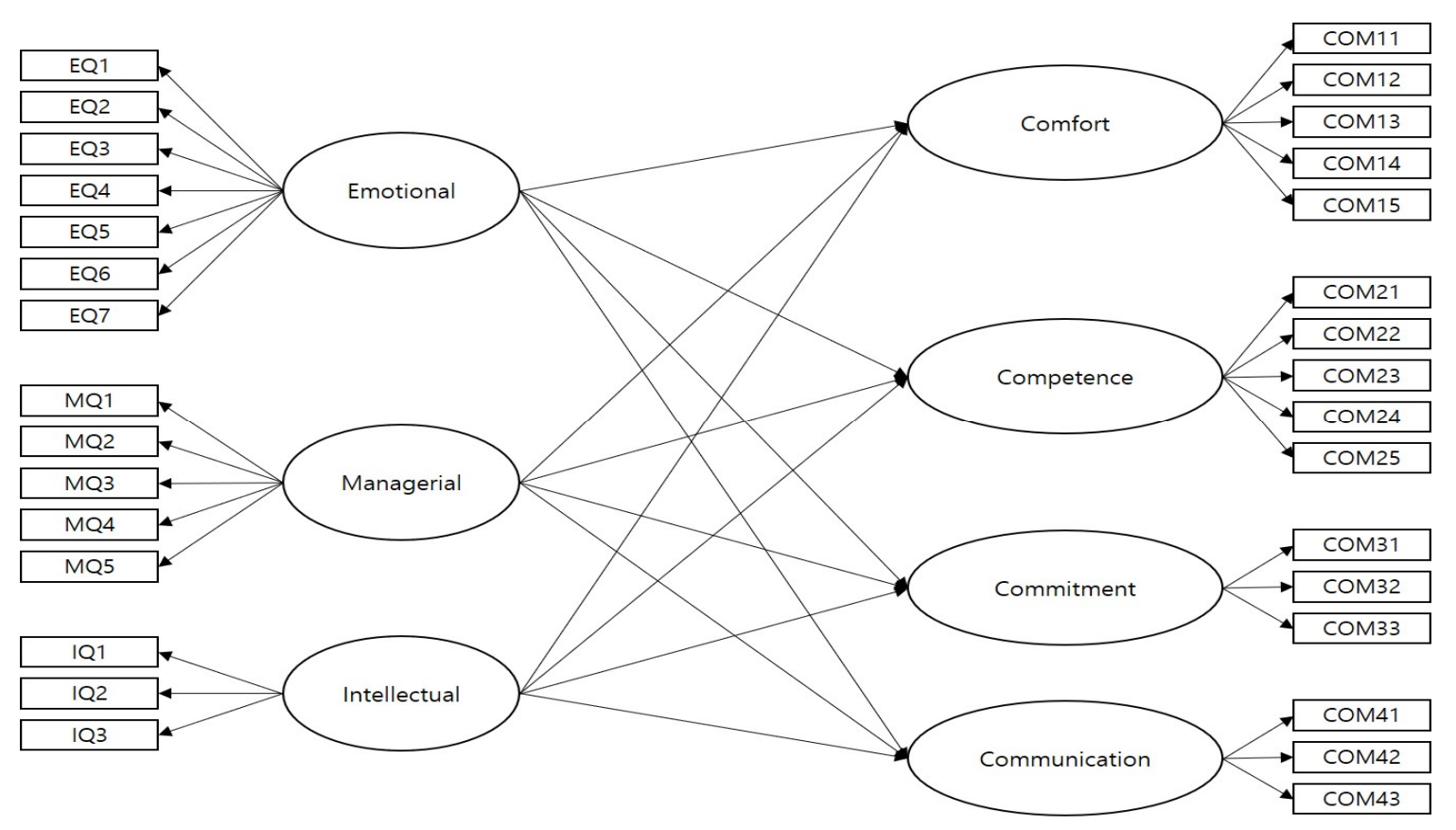

Figure 1. Research model.

The study on the effect of competence of team members on project success factor is specifically from Hypothesis 1 to Hypothesis 12. We also set up Hypothesis 13 to prove that the respondents' awareness-team members and project managers-is no different. The research hypotheses are as follows.

Hypothesis 1 (H1). The EQ of the project team member has a positive effect on the comfort of the project.

Hypothesis 2 (H2). The MQ of the project team member has a positive effect on the comfort of the project.

Hypothesis 3 (H3). The IQ of the project team member has a positive effect on the comfort of the project.

Hypothesis 4 (H4). The EQ of the project team member has a positive effect on the competence of the project.

Hypothesis 5 (H5). The MQ of the project team member has a positive effect on the competence of the project.

Hypothesis 6 (H6). The IQ of the project team member has a positive effect on the competence of the project.

Hypothesis 7 (H7). The EQ of the project team member has a positive effect on the commitment of the project.

Hypothesis $\mathbf{8}$ (H8). The MQ of the project team member has a positive effect on the commitment of the project.

Hypothesis 9 (H9). The IQ of the project team member has a positive effect on the commitment of the project.

Hypothesis 10 (H10). The EQ of the project team member has a positive effect on the communication of the project.

Hypothesis 11 (H11). The MQ of the project team member has a positive effect on the communication of the project.

Hypothesis 12 (H12). The IQ of the project team member has a positive effect on the communication of the project. 
Hypothesis 13 (H13). There is no difference in project roles (project manager and team member) on the impact of the project team member's competence on project success factor.

\subsection{Measurement Variable}

\subsubsection{Data Analysis Techniques}

A structured questionnaire was used to measure the constructs that the effect of competence of team members on project success factor. The constructs used in the questionnaire, along with their sources, are shown in Table 1. The internal consistency of the statements used in the study for the chosen constructs was verified with Cronbach's alpha. The study makes use of confirmatory factor analysis (CFA) and structural equation modeling (SEM) to ascertain significant associations among constructs included in the study. The moderating effect was verified to confirm the difference in perception of project team members' competency. Respondents were divided into project manager and team member, to verify the significance of the differences in perception.

\subsubsection{Data Collection}

Research on team members' competencies and project success factors in various industries of projects was conducted in South Korea, between January and May 2020. The research was targeted at project managers and team members who have enough experience in project implementation.

Data collection lasted five months. A total of 179 questionnaires were collected, of which 164 were analyzed, except for those answered improperly. There are 164 valid response data that consisted of all project management participants in various industries, such as manufacturing, construction, distribution, finance, pharmaceuticals, research and development (R\&D), and information and technology (IT). It is possible to study the impact of project team member's competencies on project success factors and compare the difference in perception between the project manager and project team member about the competencies of the project team member.

\subsubsection{Questionnaire Items}

The questionnaire survey technique has been widely used in the field of project management research. A questionnaire was produced to collect data for the analysis of the research model and questionnaire items. The questionnaire of this study consists of 4 sections; the first section is to profile information about the project undertaken by respondents, such as the role of the project and the size of the team. Sections 2 and 3 presented 15 competencies of project team members and 16 factors of project success variables, and the last section aimed to get the respondents and their companies' information.

The questionnaire survey was produced to collect data for analysis of the research model and the composition of questionnaire items. They were formed for each factor based on the theoretical background, as shown in Table 1, below. According to the "seven plus or minus two" principle, the model adopts a scale of 5 , which is convenient for users to judge [31]. The respondents were asked to rate the importance of each variable on a five-point Likert scale ( $1=$ strongly disagree; $2=$ disagree; $3=$ neutral; $4=$ agree; and $5=$ fully agree).

Independent variables are "competency of team member" based on the LDQs (The Leadership Questionnaire Dimensions) studies by Podgórska and Pichlak [4] and Dulewicz and Higgs [14]. The three questionnaire items were composed as emotional competence, managerial competence, and intellectual competence for team members who perform the project. Dependent variables are "project success factors" based on the studies of Zuo et al. [26] and Nguyen et al. [25]: comfort, competence, commitment, and communication as four questionnaire items for project success factor. 
Table 1. Measurement variable and questionnaire items.

\begin{tabular}{|c|c|c|c|}
\hline Construct & $\begin{array}{l}\text { Observed } \\
\text { Variable }\end{array}$ & Description & Reference \\
\hline \multirow{7}{*}{$\begin{array}{l}\text { Emotional } \\
\text { Competence }\end{array}$} & EQ1 & $\begin{array}{l}\text { The team members were aware of their own feelings and } \\
\text { managed and controlled themselves. }\end{array}$ & \multirow{15}{*}{$\begin{array}{c}\text { Boyatzis et al. [10], } \\
\text { Dulewicz and } \\
\text { Higgs [14], } \\
\text { Podgórska and } \\
\text { Pichlak [4], Müller } \\
\text { and Turner [31] }\end{array}$} \\
\hline & EQ2 & $\begin{array}{c}\text { The team members consistently maintained their } \\
\text { concentration and performed tasks in a variety of situations, } \\
\text { under pressure. }\end{array}$ & \\
\hline & EQ3 & $\begin{array}{l}\text { The team members arrived at clear decisions, using their } \\
\text { intuition, despite incomplete or ambiguous information. }\end{array}$ & \\
\hline & EQ4 & $\begin{array}{c}\text { The team members considered stakeholders' opinions or } \\
\text { requirements in arriving at decisions and proposing solutions } \\
\text { to problems and challenges. }\end{array}$ & \\
\hline & EQ5 & $\begin{array}{l}\text { The team members understood their position and persuaded } \\
\text { the other side to change a viewpoint. }\end{array}$ & \\
\hline & EQ6 & $\begin{array}{l}\text { The team members motivated and influenced each other to } \\
\text { achieve clear results. }\end{array}$ & \\
\hline & EQ7 & $\begin{array}{l}\text { The team members encouraged others with a dedicated and } \\
\text { sincere attitude. }\end{array}$ & \\
\hline \multirow{5}{*}{$\begin{array}{l}\text { Managerial } \\
\text { Competence }\end{array}$} & MQ1 & $\begin{array}{l}\text { The team members organized and coordinated the project } \\
\text { resources according to clear objects and converted long-term } \\
\text { companies into action plans. }\end{array}$ & \\
\hline & MQ2 & $\begin{array}{l}\text { The team members actively supported tasks and } \\
\text { communicated among the team members. }\end{array}$ & \\
\hline & MQ3 & $\begin{array}{l}\text { The delegated team members created ideas and solved and } \\
\text { developed problems with responsibility. }\end{array}$ & \\
\hline & MQ4 & $\begin{array}{l}\text { The team members invested time and effort to develop their } \\
\text { competencies for demanding tasks, roles, and accountabilities } \\
\text { (e.g., participation in education, training, etc.). }\end{array}$ & \\
\hline & MQ5 & $\begin{array}{l}\text { The team members were determined to achieve project } \\
\text { objectives and implement decisions. }\end{array}$ & \\
\hline \multirow{3}{*}{$\begin{array}{l}\text { Intellectual } \\
\text { Competence }\end{array}$} & IQ1 & $\begin{array}{l}\text { The team members demonstrated their ability to collect, } \\
\text { analyze, and judge information from a wide range of sources. }\end{array}$ & \\
\hline & IQ2 & $\begin{array}{l}\text { The team members demonstrated the ability to present the } \\
\text { future direction and vision of the organization. }\end{array}$ & \\
\hline & IQ3 & $\begin{array}{c}\text { The team members demonstrated the ability to think } \\
\text { strategically. (e.g., identify and balance opportunities or } \\
\text { threats influence, identify stakeholders' decision-making } \\
\text { influence, etc.) }\end{array}$ & \\
\hline \multirow{5}{*}{ Comfort } & COM11 & The adequate funds were raised throughout the project. & \multirow{16}{*}{$\begin{array}{c}\text { Chen et al. [29], } \\
\text { Nguyen et al. [25], } \\
\text { Thi and } \\
\text { Swierczek [32], } \\
\text { Zuo et al. [26] }\end{array}$} \\
\hline & COM12 & $\begin{array}{c}\text { Comprehensive contract documents related to the project } \\
\text { were well prepared. }\end{array}$ & \\
\hline & COM13 & The availability of resources needed for the project was easy. & \\
\hline & COM14 & Stakeholders had continuing involvement in the project. & \\
\hline & COM15 & There was the leadership of project managers. & \\
\hline \multirow{5}{*}{ Competence } & COM21 & There were competent project managers and team members. & \\
\hline & COM22 & $\begin{array}{c}\text { There was the latest technology utilization needed for } \\
\text { the project. }\end{array}$ & \\
\hline & COM23 & There were proper project experiences or best practices to & \\
\hline & COM24 & $\begin{array}{c}\text { reter to. } \\
\text { It consists of a project team with multidisciplinary and } \\
\text { various fields. }\end{array}$ & \\
\hline & COM25 & There was a contract with the right designer/contractor. & \\
\hline \multirow{3}{*}{ Commitment } & COM31 & $\begin{array}{c}\text { Participants in the project showed commitment to their } \\
\text { responsibilities. }\end{array}$ & \\
\hline & COM32 & There were clear objectives and scope. & \\
\hline & COM33 & There was support from top management. & \\
\hline \multirow{3}{*}{ Communication } & COM41 & Community involvement related to the project was activated. & \\
\hline & COM42 & There were clear information and communications channels. & \\
\hline & COM43 & There were frequent progress meetings. & \\
\hline
\end{tabular}




\section{Results}

\subsection{Demographic Analysis}

The demographic data for the quantitative study are as follows (see Table 2): 79.3 percent men and 20.7 percent women; and 6.7 percent was younger than 30 years old, 24.4 percent was between 30 and 39 years old, 40.9 percent was between 40 and 49 years old, 21.3 percent was between 50 and 59 years old, and 6.7 percent was 60 or older. In total, 26.8 percent of the respondents are in the IT industry, 21.3 percent in the R\&D industry, 19.5 percent in the construction industry, 16.5 percent in the manufacturing industry, 7.9 percent in the service industry, 3.7 percent in the distribution industry, 2.4 percent in the pharmaceutical industry, and 1.8 percent in the finance industry. In the studied group, the project management experience of 6.1 percent of the respondents did not exceed three years, 14.0 percent of the respondents had from three to six years of project management experience, 7.9 percent of the respondents had from seven to nine years, 19.5 percent of the respondents had from ten to fourteen years, 20.1 percent of the respondents had from fifteen to nineteen years, and 32.3 percent of the respondents had over twenty years. In total, 12.2 percent consisted of no more than five members of the project team, 38.4 percent consisted of from five to nine members, 25.0 percent consisted of from ten to twenty-nine members, 7.3 percent consisted of from thirty to forty-nine members, 6.1 percent consisted of from fifty to ninety-nine members, and finally 11.0 percent consisted of one hundred or over members. The fulfilled role in the project is 61.0 percent for the project manager and 39.0 percent for the team member. Moreover the top five competencies of team members with high average are shown in Table 3: sensitivity (EQ4), conscientiousness (EQ7), self-awareness (EQ1), influence (EQ5), and developing (MQ4).

Table 2. Characteristics of respondents.

\begin{tabular}{|c|c|c|c|c|c|c|c|}
\hline & Item & $\mathbf{N}$ & $\%$ & & Item & $\mathbf{N}$ & $\%$ \\
\hline \multirow{2}{*}{ Gender } & Male & 130 & 79.3 & \multirow{6}{*}{$\begin{array}{l}\text { Experience in } \\
\text { project } \\
\text { management }\end{array}$} & $<3$ & 10 & 6.1 \\
\hline & Female & 34 & 20.7 & & $3 \leq X<7$ & 23 & 14.0 \\
\hline \multirow{5}{*}{ Age group } & $<30$ & 11 & 6.7 & & $7 \leq X<10$ & 13 & 7.9 \\
\hline & $30 \leq X<40$ & 40 & 24.4 & & $10 \leq X<15$ & 32 & 19.5 \\
\hline & $40 \leq X<50$ & 67 & 40.9 & & $15 \leq X<20$ & 33 & 20.1 \\
\hline & $50 \leq X<60$ & 35 & 21.3 & & $\geq 20$ & 53 & 32.3 \\
\hline & $\geq 60$ & 11 & 6.7 & \multirow{6}{*}{ Size of team } & $<5$ & 20 & 12.2 \\
\hline \multirow{8}{*}{ Industry } & IT & 44 & 26.8 & & $5 \leq X<10$ & 63 & 38.4 \\
\hline & R\&D & 35 & 21.3 & & $10 \leq X<30$ & 41 & 25.0 \\
\hline & Construction & 32 & 19.5 & & $30 \leq X<50$ & 12 & 7.3 \\
\hline & Manufacturing & 27 & 16.5 & & $50 \leq X<100$ & 10 & 6.1 \\
\hline & Service & 13 & 7.9 & & $\geq 100$ & 18 & 11.0 \\
\hline & Distribution & 6 & 3.7 & \multirow{2}{*}{ Role of project } & Project manager & 100 & 61.0 \\
\hline & Pharmaceuticals & 4 & 2.4 & & Team member & 64 & 39.0 \\
\hline & Finance & 3 & 1.8 & & & & \\
\hline
\end{tabular}


Table 3. The evaluation of the importance of competence of team members.

\begin{tabular}{cccccccc}
\hline Competence & Mean & SD & Quartile 1 & Median & Quartile 3 & Min & Max \\
\hline EQ1 & 3.85 & 0.74 & 4.00 & 4.00 & 4.00 & 2 & 5 \\
\hline EQ2 & 3.54 & 0.91 & 3.00 & 4.00 & 4.00 & 1 & 5 \\
\hline EQ3 & 3.48 & 0.97 & 3.00 & 4.00 & 4.00 & 1 & 5 \\
\hline EQ4 & 4.08 & 0.95 & 4.00 & 4.00 & 5.00 & 1 & 5 \\
\hline EQ5 & 3.84 & 0.99 & 3.00 & 4.00 & 4.00 & 1 & 5 \\
\hline EQ6 & 3.81 & 0.94 & 3.00 & 4.00 & 4.75 & 1 & 5 \\
\hline EQ7 & 3.90 & 0.97 & 4.00 & 4.00 & 5.00 & 1 & 5 \\
\hline MQ1 & 3.69 & 0.97 & 3.00 & 4.00 & 4.00 & 1 & 5 \\
\hline MQ2 & 3.80 & 0.97 & 3.25 & 4.00 & 4.00 & 1 & 5 \\
\hline MQ3 & 3.73 & 0.97 & 3.00 & 4.00 & 4.00 & 1 & 5 \\
\hline MQ4 & 3.84 & 1.02 & 3.00 & 4.00 & 5.00 & 1 & 5 \\
\hline MQ5 & 3.63 & 0.97 & 3.00 & 4.00 & 4.00 & 1 & 5 \\
\hline IQ1 & 3.65 & 1.03 & 3.00 & 4.00 & 4.00 & 1 & 5 \\
\hline IQ2 & 3.34 & 1.09 & 3.00 & 3.50 & 4.00 & 1 & 5 \\
\hline IQ3 & 3.54 & 1.01 & 3.00 & 4.00 & 4.00 & 1 & 5 \\
\hline
\end{tabular}

\subsection{Reliability and Validity Analysis}

For the assessment of a model, it is imperative to measure its reliability and validity. In this study, Cronbach's alpha for establishing the consistency of the composition provided the most conservative value among the values that assess the reliability analysis [33]. The minimum accepted value for Cronbach's alpha is usually 0.7 [22,34]; however, 0.6 is generally accepted in the social science field $[34,35]$. The value of Cronbach's alpha is more than 0.69 for all the seven constructs used in this model (see Table 4.), which is a good indicator of reliability, as per the literature [34].

CFA (confirmatory factor analysis) is to test the measurement model, namely the relationship between the latent variable and observed variables. In this study, CFA was conducted to confirm the competency of team members and project success factor groupings, which are two types of reliability and validity of the measurement models to assess construct validity, i.e., convergent validity and discriminating validity [36].

The convergent validity means the degree of consistency of the observed variables that measure the construct. As a measure for convergent validity, three methods were used in this study, i.e., standardized factor loading and statistical significance, average variance extracted (AVE), and construct reliability (CR). The first way to verify convergent validity is to have standardized regression weights that are more than 0.5 and have statistical significance [37]. As a result of the analysis, the value of standardized regression weights of all variables is more than 0.5 , and the critical ratio is more than $1.965(p<0.05)$. Next, the average variance extracted (AVE) is used to evaluate the convergent validity, and the threshold value is 0.5 [38]. Finally, the value of construct reliability (CR) is one of the ways to verify convergent validity; it should be more than 0.7 [39]. The constrict reliability is evaluated via the loading of observed variables on the corresponding constructs [36]. The coefficient of composite reliability is more than 0.7 in this study. Hence, a good level of composite validity was secured. As a result of the three methods of convergent validity, although the one construction of AVE is less than 0.5 , they have validity for statistical significance $(C R>1.96 ; p<0.05)$ and construct reliability $(0.75$ or higher). If their contributions to content validity are evident, these indicators could be retained despite low loadings [40].

The value of correlation is between 0.3 and 0.85 , the measurement model is discriminant validity [5], and the square roots of AVE of each construct should be higher than the inter-construct correlation [38,41]. 
As shown in Tables 4 and 5, the discriminant validity was obtained. Hence, this measurement model is reliable and valid for further analysis.

Table 4. Results of reliability and validity analysis.

\begin{tabular}{|c|c|c|c|c|c|c|}
\hline Construct & $\begin{array}{c}\text { Observed } \\
\text { Variable }\end{array}$ & $\begin{array}{c}\text { Standardized } \\
\text { Regression Weights }\end{array}$ & $t$ Value & CR & AVE & Cronbach $\alpha$ \\
\hline \multirow{7}{*}{$\begin{array}{l}\text { Emotional } \\
\text { dimension }\end{array}$} & EQ1 & 0.782 & $12.426^{* * *}$ & \multirow{7}{*}{0.936} & \multirow{7}{*}{0.679} & \multirow{7}{*}{0.924} \\
\hline & EQ2 & 0.782 & $12.509 * * *$ & & & \\
\hline & EQ3 & 0.736 & $11.325^{* * *}$ & & & \\
\hline & EQ4 & 0.798 & $12.668^{* * *}$ & & & \\
\hline & EQ5 & 0.820 & $13.328^{* * *}$ & & & \\
\hline & EQ6 & 0.805 & $12.997^{* * *}$ & & & \\
\hline & EQ7 & 0.866 & & & & \\
\hline \multirow{5}{*}{$\begin{array}{c}\text { Managerial } \\
\text { dimension }\end{array}$} & MQ1 & 0.873 & $12.135^{* * *}$ & \multirow{5}{*}{0.914} & \multirow{5}{*}{0.682} & \multirow{5}{*}{0.907} \\
\hline & MQ2 & 0.821 & $11.266^{* * *}$ & & & \\
\hline & MQ3 & 0.881 & $12.264^{* * *}$ & & & \\
\hline & MQ4 & 0.710 & $9.447^{* * *}$ & & & \\
\hline & MQ5 & 0.772 & & & & \\
\hline \multirow{3}{*}{$\begin{array}{l}\text { Intellectual } \\
\text { dimension }\end{array}$} & IQ1 & 0.881 & $17.659 * * *$ & \multirow{3}{*}{0.927} & \multirow{3}{*}{0.809} & \multirow{3}{*}{0.931} \\
\hline & IQ2 & 0.910 & $18.885^{* * *}$ & & & \\
\hline & IQ3 & 0.926 & & & & \\
\hline \multirow{5}{*}{ Comfort } & COM11 & 0.618 & $6.007^{* * *}$ & \multirow{5}{*}{0.839} & \multirow{5}{*}{0.514} & \multirow{5}{*}{0.802} \\
\hline & COM12 & 0.793 & $6.764^{* * *}$ & & & \\
\hline & COM13 & 0.769 & $6.673^{* * *}$ & & & \\
\hline & COM14 & 0.570 & $5.988^{* * *}$ & & & \\
\hline & COM15 & 0.635 & & & & \\
\hline \multirow{5}{*}{ Competence } & COM21 & 0.802 & $8.156^{* * *}$ & \multirow{5}{*}{0.751} & \multirow{5}{*}{0.399} & \multirow{5}{*}{0.714} \\
\hline & COM22 & 0.573 & $6.995^{* * *}$ & & & \\
\hline & COM23 & 0.291 & $3.198 * *$ & & & \\
\hline & COM24 & 0.437 & $4.830 * * *$ & & & \\
\hline & COM25 & 0.655 & & & & \\
\hline \multirow{3}{*}{ Commitment } & COM31 & 0.811 & $9.034^{* * *}$ & \multirow{3}{*}{0.807} & \multirow{3}{*}{0.602} & \multirow{3}{*}{0.707} \\
\hline & COM32 & 0.596 & $7.752 * * *$ & & & \\
\hline & COM33 & 0.656 & & & & \\
\hline \multirow{3}{*}{ Communication } & COM41 & 0.535 & $5.932 * * *$ & \multirow{3}{*}{0.836} & \multirow{3}{*}{0.635} & \multirow{3}{*}{0.692} \\
\hline & COM42 & 0.792 & $7.173^{* * *}$ & & & \\
\hline & COM43 & 0.692 & & & & \\
\hline
\end{tabular}

(1) Note: $\chi^{2}$ (df) 935.971(413), $p$ 0.0, $\chi^{2} /$ df 2.266, IFI 0.851, TLI 0.829, CFI 0.849, RMSEA 0.088. (2) Note: AVE (Average Variance Extracted) (3) Note: ${ }^{* *} p<0.01,{ }^{* * *} p<0.001$. 
Table 5. Results of discriminant validity.

\begin{tabular}{cccccccc}
\hline & EQ & MQ & IQ & COM1 & COM2 & COM3 & COM4 \\
\hline Emotional Competence (EQ) & 0.83 & & & & & & \\
\hline Managerial Competence (MQ) & 0.80 & 0.83 & & & & & \\
\hline Intellectual Competence (IQ) & 0.65 & 0.70 & 0.90 & & & & \\
\hline Comfort (COM1) & 0.58 & 0.57 & 0.55 & 0.72 & & & \\
\hline Competence (COM2) & 0.80 & 0.83 & 0.76 & 0.88 & 0.63 & & \\
\hline Commitment (COM3) & 0.62 & 0.67 & 0.55 & 0.82 & 0.81 & 0.78 & \\
\hline Communication (COM4) & 0.52 & 0.65 & 0.54 & 0.70 & 0.75 & 0.95 & 0.80 \\
\hline
\end{tabular}

(1) Note: Italic values are the square roots of the AVE value of constructs.

\subsection{Assessment of Structure Fit of the Model}

In the SEM analysis (see Table 6), it is a good fit, as reflected by values of the model fit indices and residual value. The $\chi^{2}(p)$ was $908.849(0.00)$, and the $\chi^{2} /$ degree of freedom was 2.190 . The value of IFI was 0.859 , and the value of TLI, which indicates the explanatory power of the structural model was 0.840 . The value of CFI was 0.857 (close to 0.9 ), which was not affected by the sample and represented the explanatory power of the model. The value of RMSEA was 0.085 (less than 1.0), and thus it was good enough, so that the final structural equation fitness analysis was proven as an appropriate one.

As shown in Table 6, the structural equation model analysis was conducted, and 5 out of the 12 hypotheses were rejected.

Table 6. Results of the hypothesis test.

\begin{tabular}{ccccc}
\hline & Hypotheses & SE & CR & Adoption \\
\hline $\mathrm{H}_{1}$ & $\mathrm{EQ} \rightarrow$ Comfort & 0.104 & 1.924 & Rejected \\
$\mathrm{H}_{2}$ & $\mathrm{MQ} \rightarrow$ Comfort & 0.123 & 1.159 & Rejected \\
$\mathrm{H}_{3}$ & $\mathrm{IQ} \rightarrow$ Comfort & 0.072 & $2.129^{*}$ & Accepted \\
\hline $\mathrm{H}_{4}$ & $\mathrm{EQ} \rightarrow$ Competence & 0.091 & $2.934^{* *}$ & Accepted \\
$\mathrm{H}_{5}$ & $\mathrm{MQ} \rightarrow$ Competence & 0.110 & $2.946^{* *}$ & Accepted \\
$\mathrm{H}_{6}$ & $\mathrm{IQ} \rightarrow$ Competence & 0.063 & $3.166^{* *}$ & Accepted \\
\hline $\mathrm{H}_{7}$ & $\mathrm{EQ} \rightarrow$ Commitment & 0.098 & $1.957^{*}$ & Accepted \\
$\mathrm{H}_{8}$ & $\mathrm{MQ} \rightarrow$ Commitment & 0.118 & $2.580^{* *}$ & Accepted \\
$\mathrm{H}_{9}$ & $\mathrm{IQ} \rightarrow$ Commitment & 0.067 & 0.654 & Rejected \\
\hline $\mathrm{H}_{10}$ & $\mathrm{EQ} \rightarrow$ Communication & 0.068 & 0.320 & Rejected \\
$\mathrm{H}_{11}$ & $\mathrm{MQ} \rightarrow$ Communication & 0.093 & $3.208^{* * *}$ & Accepted \\
$\mathrm{H}_{12}$ & $\mathrm{IQ} \rightarrow$ Communication & 0.047 & 1.332 & Rejected \\
\hline
\end{tabular}

(1) Note: $\chi^{2}$ (df) 908.749(415), $p$ 0.0, $\chi^{2} /$ df 2.190, IFI 0.859, TLI 0.840, CFI 0.857, RMSEA 0.085. (2) Note: * $p<0.05$, ** $p<0.01, * * * p<0.001$.

\subsubsection{The Result of Hypotheses 1 to 3 Verification}

In observation of the result of Hypotheses 1 to 3 verification, the effect of team member's intellectual competence on comfort, which is a factor of project success, is statistically significant. Hypotheses 1 and 2, however, are rejected because they were not statistically significant. Among the competencies of team members, the value of $t$, which represented intellectual competence, was $2.129(p<0.05)$, turning out to affect comfort positively (see Table 6).

Therefore, Hypothesis 3 supported that team members' intellectual competence has a positive effect on the comfort of carrying out the project. These findings show that improvement of the intellectual competence of team members facilitates the participation of the necessary contract documents, funds, resources, and stakeholders' involvement for the project success. 


\subsubsection{The Result of Hypotheses 4 to 6 Verification}

In observation of the result of Hypotheses 4 to 6 verification, the effect of all competence of team members on competence, which is a factor of project success, is statistically significant. The value of $t$, which is emotional competence of team members, was $2.934(p<0.01)$, turning out to affect the competence positively (see Table 6). The value of $t$, which is team member's managerial competence was $2.946(p<0.01)$, turning out to affect the competence of the project success factor positively (see Table 5). The value of $t$, which is the intellectual competence of team members, was $3.166(p<0.01)$, turning out to affect competence of project success factor positively (see Table 6).

Therefore, Hypotheses 4 to 6 supported that the emotional, managerial, and intellectual competence of the team members have a positive effect on the competence of carrying out the project. These findings show that the improvement of all competence of team members contributed to utilize the competent project managers and team members and to build a multidisciplinary team, technology utilization, and proper best practices for the project success.

\subsubsection{The Result of Hypotheses 7 to 9 Verification}

In observation of the result of Hypotheses 7 to 9 verification, the effect of team member's emotional and managerial competence on commitment, which is a factor of project success, is statistically significant. Hypothesis 9, however, was rejected because it is not statistically significant. The value of $t$, which is the emotional competence of team members, was $1.957(p<0.05)$, turning out to affect commitment positively (see Table 6). The value of $t$, which is the managerial competence of team members, was $2.580(p<0.01)$, turning out to affect the commitment of the project success factor positively (see Table 6).

Therefore, Hypotheses 7 and 8 supported that team members' emotional and managerial competence has a positive effect on the commitment of carrying out the project. These findings show that improvement of the emotional and managerial competence of team members helped to achieve project success, for example, by taking project participants' responsibility, setting clear objectives and scope, and receiving support from top management.

\subsubsection{The Result of Hypotheses 10 to 12 Verification}

In observation of the result of Hypotheses 10 to 12 verification, the effect of team member's managerial competence on communication, which is a factor of project success, is statistically significant. Hypotheses 10 and 12, however, were rejected because they are not statistically significant. The value of $t$, which is the managerial competence of team members, was $3.208(p<0.001)$, turning out to affect communication of project success factor strong positively (see Table 6).

Therefore, Hypothesis 11 supported the idea that team members' managerial competence has a strong positive effect on the communication of carrying out the project. These findings show that improving the managerial competence of team members contributes to community participation, clear information channels, and frequent meetings, thereby increasing project success.

\subsubsection{The Result of Hypothesis 13 Verification}

Finally, to verify the moderating effect of the difference in perception by project role, the analysis was conducted. The project role was divided into project manager and team member groups, and we verified the differences in perception about the effect of team member's competencies on project success factor.

For the analysis, two groups were set up, a constraint model of the project manager group and the non-constraint model of the team member group. Of the total 164 respondents, the project manager group consists of 100 , and the team member group consists of 64 . Moreover, the moderating effect was determined based on statistical significance. The result of the analysis (see Table 7) was no statistical significance to the moderating effect $(p=0.051)$. It means that the null hypothesis is not rejected. Thus, 
there is no difference between the project manager group and team member group in regard to the team member's competence impact on project success factor.

Table 7. Results of moderating effects.

\begin{tabular}{cccc}
\hline Model & $p$ & CMIN & DF \\
\hline Constraint model & 0.051 & 20.953 & 12 \\
\hline
\end{tabular}

\section{Conclusions}

\subsection{Discussion: Competence of Team Members and Open Innovation}

This study aimed to identify team member's competencies required for project management in various industries and to investigate the influence of these competencies of team members on project success factors. Through empirical research through SEM, 15 competencies of team members under three dimensions and 16 project success factors under four dimensions were identified, and seven hypotheses of the total 13 were adopted in the hypothesis model. As a result, the impact of team members' competencies on project success factors was statistically significant.

In summary, the intellectual dimension (IQ) of the team member is an important factor in comfort and competence in project success. The ability to critically analyze and judge team members from a vision, imagination, and strategic perspective will help the project to be implemented comfortably with the business cases and help the project team make accurate decisions. In particular, unlike other competencies, we found that team members' intellectual competencies are most important to funding the project, using resources, and continuing to involve stakeholders in the project. The managerial dimension (MQ) of the team member is an important factor in competence, commitment, and communication of project success factors. The capability of team members to manage resources, engage communication, empower and achieve goals to promote communication within the project, develop their own capabilities by participating in education or training, utilize appropriate knowledge or skills to create best practices, and enable continuous meetings and clear information channels for the project is important. In addition, managerial competencies are the only independent variable that affect communication among the $4 \mathrm{COMs}$. Emotional dimension (EQ) of team members is an important factor in competence and commitment. Team members' self-awareness, emotional resilience, intuitiveness, sensitivity, motivation, and conscientiousness help them succeed by fulfilling their responsibilities within clear objectives and scope, making decisions quickly and accurately, and having the will to accomplish the project.

The study presented in this paper extends the research on competencies of project management fields in three ways. First, this study empirically analyzed core competencies of the project team members that are needed to carry out the project successfully. The results obtained support the importance of the personality, knowledge, and skills of team members to the success of the project. This finding shows that team members' mindset and behavior are considered as a response to the growing demand for project success. This means that our research, which reveals the importance of a practitioner's leadership capabilities, is a new level of competition as an open innovation [42].

Second, it was confirmed that team members have equivalent competencies as the project manager, based on LDQ. Previous studies measured project managers based on LDQ questionnaires, but this study is meaningful because it measured team members that reflect a modern and innovative perspective. It also shows that the competence of a team member is being specialized according to Hypothesis 13-project manager and team members have the same perception.

Finally, the result of the analysis shows the relationship between three competences-emotional, managerial, and intellectual—of team members and project success for different industries. According to these analyzes, project team members from various industries need to be professional and flexible like the PM. In the fourth industrial revolution, the needs of society and the market must be more 
actively and directly responded to than before [43]. Team members can play a specialized role for open innovation in the enterprise, extending the business model to meet market demands.

In conclusion, this white paper aims to explore new approaches to project team competency by defining the project team's competency as the team members' competency. Based on project leadership theory, team members have defined the features necessary for successful project management implementation. In the open innovation management literature, it is widely acknowledged that individuals play an essential role in collaborative knowledge creation processes. The required skill level of the competency in open innovation might be higher than in other projects [44]. Therefore, on the open side, the higher the team's capacity, the more successful the project will be.

From an academic perspective, this study means that by defining team members' competence from an innovation perspective, it has laid the foundation for project success and sustainable competitive advantage. The practical implications of this study are that by distributing manager-oriented competency development to team members, companies can increase their business competitiveness. Podgórska and Pichlak suggested the need to develop communication skills, empathy, emotional resilience, and strategic perspectives in projects with a high degree of complexity [4], and in this paper, the emotional dimensions of team members, such as self-awareness, intuition, sensitivity, and motivation, were concluded. It helps motivate and achieve project goals.

Therefore, from a strategic point of view, we have proposed that the company understands the characteristics of current and future projects and fosters team members who can carry out the project. It can be raised through organizational training.

\subsection{Limitations and Further Research Streams}

The limitation inherent in this paper holds to the case study in-depth analysis of one organization. Although this study has identified the relevance of the theoretical framework and the understanding of the organizational management of members in the project, there is a limit to examining the relationship between team members' capability to change over time and project success factors.

Further research opportunities exist to investigate the influence of moderating factors, such as project team size and complexity, and the existence of a career development system in the company, concerning the link between team member's competencies and project success factors. We have gained the insight that culture for open innovation dynamics is an important driving force for innovation and that we need to understand the team structure to control complexity [45]. In the future, projects in the converted industry will appear. In the case of a converted industry, strategies focused on the business model are useful in the early stage, while one focused on technology is active in the maturity stage [46]. If the team members carrying out the project have the skills, knowledge, and management skills in a strategic direction, it will also help to carry out the project in a converted industry.

Author Contributions: All authors significantly contributed to the scientific study and writing. M.O. contributed to the overall idea, design, and analysis of the survey and writing of the manuscript; S.C. contributed to the detailed writing, ideas, and discussions on open innovation, as well as the preparation and publishing of the paper. All authors have read and agreed to the published version of the manuscript.

Funding: This research received no external funding.

Conflicts of Interest: The authors declare no conflict of interest.

\section{References}

1. Steinfort, P.; Walker, D.H. What Enables Project Success: Lessons from Aid Relief Projects; Project Management Institute: Newtown Square, PA, USA, 2011; p. 225.

2. Alvarenga, J.C.; Branco, R.R.; Guedes, A.L.A.; Soares, C.A.P.; e Silva, W.D. The project manager core competencies to project success. Int. J. Manag. Proj. Bus. 2019, 13, 277-292. [CrossRef]

3. Turner, J.R.; Müller, R. Choosing Appropriate Project Managers: Matching Their Leadership Style to the Type of Project; Project Management Institute: Newtown Square, PA, USA, 2006. 
4. Podgórska, M.; Pichlak, M. Analysis of project managers' leadership competencies: Project success relation: What are the competencies of polish project leaders? Int. J. Manag. Proj. Bus. 2019, 12, 869-887. [CrossRef]

5. Kerzner, H. Project Management: A Systems Approach to Planning, Scheduling, and Controlling, 11th ed.; John Wily \& Sons Inc.: New York, NY, USA, 2013.

6. Carte, T.A.; Chidambaram, L.B.; Becker, A. Emergent leadership in self-managed virtual teams: A longitudinal study of concentrated and shared leadership behaviors. Group Decis. Negot. 2006, 15, 323-343. [CrossRef]

7. Yun, J.J.; Won, D.K.; Park, K.B. Entrepreneurial cyclical dynamics of open innovation. J. Evol. Econ. 2018, 28, 1151-1174. [CrossRef]

8. Boyatzis, R.E. Transforming Qualitative Information: Thematic Analysis and Code Development; Sage: Thousand Oaks, CA, USA, 1998.

9. Boyatzis, R.E. Competencies in the twenty-first century. J. Manag. Dev. 2008, 27, 5-12. [CrossRef]

10. Boyatzis, R.; Boyatzis, R.E.; Ratti, F. Emotional, social and cognitive intelligence competencies distinguishing effective Italian managers and leaders in a private company and cooperatives. J. Manag. Dev. 2009, 28, 821-838. [CrossRef]

11. Spencer, L.M.; Spencer, S.M. Competence at Work: Models for Superior Performance; John Wiley \& Sons: New York, NY, USA, 1993.

12. Collins, J.C.; Parras, J.I. Building your company's vision. Harv. Bus. Rev. 1996, 74, 65-77.

13. Higgs, M.J.; Rowland, D. Developing change leaders: Assessing the impact of a development programme. Chang. Manag. J. 2001, 2, 47-64. [CrossRef]

14. Dulewicz, V.; Higgs, M. Assessing leadership styles and organisational context. J. Manag. Psychol. 2005, 20, 105-123. [CrossRef]

15. Christenson, D.; Walker, D.H.T. Understanding the role of "vision" in project success. Proj. Manag. J. 2004, 35, 39-52. [CrossRef]

16. Dainty, A.R.J.; Cheng, M.; Moore, D.R. A competency-based performance model for construction project managers. Constr. Manag. Econ. 2004, 22, 877-886. [CrossRef]

17. Prabhakar, G.P. Switch leadership in projects: An empirical study reflecting the importance of transformational leadership on project success across twenty-eight nations. Proj. Manag. J. 2005, 36, 53-60. [CrossRef]

18. Crawford, L.H.; Hobbs, J.B.; Turner, J.R. Project Categorization Systems; PMI: Newton Square, PA, USA, 2005.

19. Dvir, D.; Sadeh, A.; Malach-Pines, A. Projects and project managers: The relationship between project manager's personality, project, project types, and project success. Proj. Manag. J. 2006, 37, 36-48. [CrossRef]

20. Geoghegan, L.; Dulewicz, V. Do project managers' leadership competencies contribute to project success? Proj. Manag. J. 2008, 39, 58-67. [CrossRef]

21. Turner, J.R.; Müller, R.; Dulewicz, V. Comparing the leadership styles of functional and project managers. Int. J. Manag. Proj. Bus. 2009, 2, 198-216. [CrossRef]

22. Robinson, J.P.; Shaver, P.R. Measures of Psychological Attitudes; Survey Research Center Institute for Social Research, University of Michigan: Ann Arbor, MI, USA, 1973.

23. Jugdev, K.; Müller, R. A retrospective look at our evolving understanding of project success. Proj. Manag. J. 2005, 36, 19-31. [CrossRef]

24. Kerzner, H. Advanced Project Management: Best Practices on Implementation, 2nd ed.; John Wiley \& Sons: Hoboken, NJ, USA, 2004.

25. Nguyen, L.D.; Ogunlana, S.O.; Lan, D.T.X. A study on project success factors in large construction projects in Vietnam. Eng. Constr. Archit. Manag. 2004, 11, 4040-4413. [CrossRef]

26. Zuo, J.; Zhao, X.; Gao, S. Soft skills of construction project management professionals and project success factors. Eng. Constr. Archit. Manag. 2018, 25, 425-442. [CrossRef]

27. Pinto, J.K.; Slevin, D.P. Project success: Definitions and measurement techniques. Proj. Manag. J. 1988, 19, $67-72$.

28. Creasy, T.; Anantatmula, V.S. From every direction-How personality traits and dimensions of project managers can conceptually affect project success. Proj. Manag. J. 2013, 44, 36-51. [CrossRef]

29. Chen, W.T.; Chen, T.T.; Sheng Lu, C.; Liu, S.S. Analyzing relationships among success variables of construction partnering using structural equation modeling: A case study of Taiwan's construction industry. J. Civ. Eng. Manag. 2012, 18, 783-794. [CrossRef]

30. Choi, S.; Park, K.B.; Shim, S.O. Comparing validity of risk measures on newsvendor models in open innovation perspective. J. Open Innov. Technol. Mark. Complex. 2018, 4, 1. [CrossRef] 
31. Müller, R.; Turner, R. Leadership competency profiles of successful project managers. Int. J. Proj. Manag. 2010, 28, 437-448. [CrossRef]

32. Thi, C.H.; Swierczek, F.W. Critical success factors in project management: Implication from Vietnam. Asia Pac. Bus. Rev. 2010, 16, 567-589. [CrossRef]

33. Carmines, E.G.; Zeller, R.A. Reliability and Validity Assessment; Sage University Paper series on Quantitative Applications in the Social Sciences; Sage Publications: Beverly Hills, CA, USA, 1979.

34. Hair, J.F. Multivariate Data Analysis, 5th ed.; Bookman (Portuguese): Porto Alegre, Brazil, 2005.

35. Robinson, J.P.; Shaver, P.R.; Wrightsman, L.S. Criteria for Scale Selection and Evaluation in Measures of Personality and Social Psychological Attitudes; Academic Press: San Diego, CA, USA, 1991.

36. Shan, M.; Chan, A.P.C.; Le, Y.; Hu, Y. Investigating the effectiveness of response strategies for vulnerabilities to corruption in the Chinese public construction sector. Sci. Eng. Ethics 2015, 21, 683-705. [CrossRef]

37. Anderson, J.C.; Gerbing, D.W. Structural equation modeling in practice: A review and recommended two-step approach. Psychol. Bull. 1988, 103, 411-423. [CrossRef]

38. Fornell, C.; Larcker, D.F. Evaluating structural equation models with unobservable variables and measurement error. J. Mark. Res. 1981, 18, 39-50. [CrossRef]

39. Hair, J.F.; Anderson, R.E.; Tatham, R.L.; Black, W.C. Multivariate Data Analysis with Readings; Prentice Hall: Englewood Cliffs, NJ, USA, 1998.

40. Hair, J.F.; Ringle, C.M.; Sarstedt, M. PLS-SEM: Indeed a Silver Bullet. J. Mark. Theory Pract. 2011, 19, 139-152. [CrossRef]

41. Chin, W.W. The Partial Least Squares Approach to Structural Equation Modeling; Marcoulides, G.A., Ed.; Modern Methods for Business Research, Lawrence Erlbaum Associates: Mahwah, NJ, USA, 1998; pp. 295-335.

42. Henkel, J.; Schöberl, S.; Alexy, O. The emergence of openness: How and why firms adopt selective revealing in open innovation. J. Open Innov. Technol. Mark. Complex. 2014, 5, 879-890. [CrossRef]

43. Yun, J.J.; Kim, D.C.; Yan, M.R. Open Innovation Engineering-Preliminary Study on New Entrance of Technology to Market. J. Open Innov. Technol. Mark. Complex. 2020, 9, 791. [CrossRef]

44. Chartenier, E.; Verstegen, J.A.A.M.; Biemans, H.J.A.; Mulder, M.; Omta, O.S.W.F. Identification of competencies for professionals in open innovation teams. $R$ D Manag. 2010, 40, 271-280. [CrossRef]

45. Yun, J.J.; Zhao, X.; Jeng, K.H.; Yigitcablar, T. The Culture for Open Innovation Dynamics. Sustainability 2020, 12, 5076. [CrossRef]

46. Yun, J.J.; Won, D.K.; Park, K.B.; Jeong, E.S.; Zhao, X. The role of a business model in market growth: The difference between the converted industry and the emerging industry. Technol. Forecast. Soc. Chang. 2019, 146, 462-534. [CrossRef]

(C) 2020 by the authors. Licensee MDPI, Basel, Switzerland. This article is an open access article distributed under the terms and conditions of the Creative Commons Attribution (CC BY) license (http://creativecommons.org/licenses/by/4.0/). 